\title{
Komposisi Kimia dan Korelasi Beberapa Karakteristik Daging Pipi Sapi Bali
}

\section{Chemical Composition and Correlation of Some Characteristics of Beef Bali Cheek-Meat}

\author{
Rosmawati ${ }^{1 *}$, M. I. Said ${ }^{2}$, E. Abustam ${ }^{3}$, dan A. B. Tawali ${ }^{4}$ \\ ${ }^{1}$ Universitas Muhammadiyah Kendari, Jalan K.H. Ahmad Dahlan No. 10 Kendari 93117 - Indonesia \\ ${ }^{2}$ Laboratorium Teknologi Pengolahan Sisa Hasil Ternak, Fakultas Peternakan, Universitas Hasanuddin, \\ Jalan Perintis Kemerdekaan, Makassar 90245 - Indonesia \\ ${ }^{3}$ Laboratorium Ilmu Daging dan Teknologi Hasil Ternak, Fakultas Peternakan, Universitas Hasanuddin, \\ Jalan Perintis Kemerdekaan, Makassar 90245 - Indonesia \\ ${ }^{4}$ Laboratorium Ilmu dan Teknologi Pangan, Fakultas Pertanian, Universitas Hasanuddin, Jalan Perintis \\ Kemerdekaan, Makassar 90245 - Indonesia \\ *Corresponding E-mail: rosrossie.ummumuthe@gmail.com \\ (Diterima: 23 Oktober 2019; Disetujui: 22 Desember 2019)
}

\begin{abstract}
ABSTRAK
Daging pipi termasuk hasil samping pemotongan ternak dan tidak dikategorikan sebagai karkas. Tujuan penelitian adalah mengidentifikasi sifat fisikokimia daging pipi sapi Bali untuk menjadi pertimbangan bahan baku dalam berbagai proses pengolahan pangan berbasis hewani. Sampel berasal dari Rumah Potong Hewan Tamangapa Makassar yang dianalisis setelah enam jam pemotongan. Hasil analisis menunjukkan komposisi kimia daging pipi menyerupai daging skeletal pada umumnya. Rataan $\mathrm{pH}$ otot berkisar pada 5,73 sampai 6,01, daya mengikat air sebagai refleksi dari kadar air lepas 32,64 sampai 51,64 mg, susut masak 26,84 sampai 35,90\%, daya putus daging 2,96 sampai $3,53 \mathrm{~kg} / \mathrm{cm} 2$, dan warna menunjukkan tingkat kecerahan (L) 33,86 sampai 43,13, kemerahan (a*) 18,20 sampai 24,78, dan kekuningan (b*) 0,80 sampai 3,85 . Koefisien korelasi antara $\mathrm{pH}$ dan daya mengikat air adalah $\mathrm{r}=-0,92$, artinya semakin rendah $\mathrm{pH}$ maka kemampuan otot melepaskan air semakin tinggi. Terdapat korelasi sangat kuat antara $\mathrm{pH}$ dan susut masak, yaitu $\mathrm{r}=-0,84$, menunjukkan semakin rendah $\mathrm{pH}$ daging susut masak semakin tinggi. Kofisien korelasi antara nilai $L$, $\mathrm{a}^{*}$ dan $\mathrm{b}^{*}$, secara berturut turut terhadap $\mathrm{pH}$ daging pipi adalah $\mathrm{r}=-0,62, \mathrm{r}=-0,71$, dan $\mathrm{r}=$ $-0,56$.
\end{abstract}

Kata kunci: daging pipi, daya mengikat air, daya putus daging, $\mathrm{pH}$, susut masak

\section{ABSTRACT}

Cheek-meat is a by-product of slaughtering livestock and is not categorized as a carcass. The research objective was to identify the physicochemical characteristics of Bali beef cheek meat to be considered raw materials in various food processing. Samples came from Slaughterhouse Tamangapa-Makassar which was analyzed after six hours of slaughter. Generally, the results of the analysis indicated that the chemical composition of cheek meat resembled skeletal meat. The average muscle pH between 5.73 to 6.01, water holding capacity as a reflection of released water were 32.64 to $51.64 \mathrm{mg}$, cooking losses were 26.84 to $35.90 \%$, shear force were 2.96 to $3.53 \mathrm{~kg} / \mathrm{cm} 2$, and the color shows the level of brightness (L) 33.86 to 43.13 , reddish ( $\left.a^{*}\right) 18.20$ to 24.78 , and yellowish ( $\left.b^{*}\right) 0.80$ to 3.85 . The value of $r$ to the linkage between $p H$ and water holding capacity was $r=-0.92$, meaning the $\mathrm{pH}$-lower caused the ability of muscles to release water was higher. The correlation between $p H$ and cooking losses was very strong $(r=-0.84)$ which means if the cheek meat $\mathrm{pH}$-lower leads the higher of cooking losses. Correlation coefficient between value of $L$, $a^{*}$ and $b^{*}$ respectively to cheek meat $p H$ were $r=-0.62, r=-0.71$, and $r=-0.56$.

Keyword: cheek meat, cooking loss, $p H$, shear force, water-holding capacity 


\section{PENDAHULUAN}

Sisa hasil pemotongan ternak adalah semua bagian dari tubuh ternak yang tidak dikategorikan sebagai karkas, dan untuk seekor ternak sapi jumlahnya sekitar $44 \%$ dari berat hidupnya (Marti et al., 2012). Diperkirakan bahwa $11,4 \%$ dari pendapatan kotor dari daging sapi berasal dari produk sampingan, dihasilkan oleh rumah potong, pengolah daging, grosiran dan pabrik pengolahan lemak (Jayathilakan et al., 2012). Daging pipi (Musculus masseter) merupakan jenis daging yang mempunyai karakteristik menyerupai daging merah pada umumnya, misalnya daging bagian abdominal (Ranken, 2000). Daging pipi termasuk hasil samping pemotong ternak dan tidak dikategorikan sebagai karkas. Daging yang terdapat pada bagian tulang pipi ini menurut Pereira et al. (2016) merupakan jenis daging dengan kemampuan mengikat air sedang (intermediate water holding capacity) dibandingkan dengan daging skeletal.

Sangat sedikit informasi penelitian yang dilaporkan terkait komposisi dan karakteristik daging pipi (Musculus masseter), kecuali yang dilaporkan oleh Talmant et al. (1986); Vasudevan and Venkataramanujam (2012). Informasi terkait daging pipi sapi Bali sejauh ini belum ada. Daging pipi termasuk salah satu jenis daging yang sering digunakan dalam olahan makanan khas Sulawesi Selatan seperti "pallu basa", karena memiliki rasa khas, tidak berlemak, dan agak kenyal.

Secara visual, daging pipi menyerupai daging skeletal pada umumnya, meskipun demikian daging ini dikategorikan sebagai daging non-karkas karena posisi anatomisnya terletak pada bagian kepala. Otot pipi adalah bagian dari otot rangka yang memiliki fungsi anatomis tersendiri, tetapi karakteristik ototnya tidak berbeda jauh dengan otot-otot pada bagian tubuh lainnya.

Daging pipi tersusun atas komposit serat otot, jaringan ikat, adipose, vascular dan saraf, sebagaimana daging skeletal pada umumnya (Listrat et al., 2016). Pada hampir seluruh permukaan daging pipi terdapat penebalan jaringan ikat yang cukup padat. Jaringan ikat yang padat ini mungkin ada hubungannya dengan fungsi kerja dari otot pipi yang banyak melakukan aktivitas bergerak ketika hewan mengunyah/memamah biak (Purslow, 2005), akibatnya terjadi penebalan jaringan ikat di sekitar bagian otot. Keadaan ini dapat mempengaruhi sifat fisikokimianya (Hoffman et al., 2012).

Ada beberapa sifat fisiko-kimia daging pipi yang akan diamati, dengan demikian, meskipun informasi yang disajikan terbatas, penelitian ini akan membantu dalam mendeskripsikan otot pipi sapi sebagai informasi untuk penelitian selanjutnya. Tujuan penelitian ini adalah mengkarakterisasi sifat fisikokimia daging pipi, sehingga dapat menjadi pertimbangan sebagai daging alternatif dalam berbagai proses pengolahan pangan seperti bakso, sosis dan produkproduk berbasis hewani lainnya.

\section{METODE}

\section{Hewan, Kondisi, dan Sampling}

Daging pipi adalah sampel utama penelitian, disampling dari lima ekor sapi Bali umur sekitar 4 sampai 5 tahun, tanpa melalui perlakuan apapun selain dipuasakan selama 24 jam. Ternak dipotong di rumah potong hewan Tamangapa Makassar, Sulawesi Selatan, Indonesia. Preparasi dan analisis sampel dilakukan di Laboratorium Teknologi Daging dan Telur dan Laboratorium Kimia Makanan Ternak Fakultas Peternakan Universitas Hasanuddin.

Setelah proses pengkarkasan, daging pipi dilepaskan dari kepala. Daging diangkut ke laboratorium menggunakan cool box. Beberapa karakteristik daging pipi diamati setelah enam jam postmortem yang dihitung dari mulai waktu penyembelihan, dan parameter diukur dalam suhu kamar. Waktu enam jam setelah pemotongan menjadi acuan waktu pengamatan, sebagai alasannya bahwa umumnya masyarakat setempat mulai mengolah daging setelah penyembelihan pada 
rentang waktu tersebut.

\section{Teknik Analisis}

Analisis Proksimat. Analisis proksimat dilakukan menggunankan metode AOAC (1995). Kadar air diukur secara gravimetric dengan mengoven sampel pada suhu $105^{\circ} \mathrm{C}$ hingga konstan. Kadar protein kasar ditentukan dengan metode Kjeldahl menggunakan faktor konversi nitrogen $(6,25$ $\mathrm{x}$ N). Kandungan lemak kasar ditentukan menggunakan metode Soxhlet. Kandungan abu dianalisis melalui proses incinerasi pada tungku pembakaran suhu $500{ }^{\circ} \mathrm{C}$ selama 16 jam.

Nilai pH. Nilai $\mathrm{pH}$ ditentukan melalui $\mathrm{pH}$ meter (Lutron $\mathrm{pH}-201$ ) dengan cara memasukkan elektroda khusus ke dalam daging. Sebelum pengukuran, $\mathrm{pH}$ meter dikalibrasi pada bufer $\mathrm{pH} 4$ dan 7. Pembacaan skala angka pada layar dilakukan setelah angka yang ditunjukkan stabil.

Keempukan. Keempukan dinyatakan sebagai daya putus daging dan diukur menggunakan CD-Shear Force, berdasarkan metode Abustam (2012). Daging ditempatkan pada celah CD-Shear force yang dilengkapi probe pisau-tumpul untuk memotong sampel. Semakin besar beban yang digunakan untuk memutus daging maka daging semakin alot. Nilai daya putus daging dinyatakan dalam $\mathrm{kg} /$ $\mathrm{cm}^{2}$.

$$
\mathrm{A}=\mathrm{A}^{1 / \mathrm{L}}
$$

Keterangan:

$\mathrm{A}=$ Daya putus daging $\left(\mathrm{kg} / \mathrm{cm}^{2}\right)$

$\mathrm{A}^{1}=$ Tekanan yang digunakan $(\mathrm{kg})$

$\mathrm{L}=$ Luas penampang sampel $\left(\pi \mathrm{r}^{2}\right)=1,266 \mathrm{~cm}^{2}$

Daya Mengikat Air. Daya mengikat air diukur menggunakan metode penekanan (Filter-Paper Press method) berdasarkan metode Hamm dengan beberapa modifikasi oleh Abustam (2012), sesuai dengan persamaan berikut:

$$
\mathrm{H}_{2} \mathrm{O}(\mathrm{mg})=\frac{\text { Daerah basah }\left(\mathrm{cm}^{2}\right)}{0,0949}-8.0
$$

Susut Masak. Sebanyak 40 g sampel dimasukkan dalam plastik klip kemudian dimasak dalam waterbath suhu $70^{\circ} \mathrm{C}$ selama 30 menit. Sampel yang telah dimasak dikeluarkan dari plastik dan dibiarkan hingga sekitar 1 jam sehingga air yang masih menempel pada bagian luar sampel telah menguap. Sampel ditimbang untuk medapatkan nilai susut masak, yang dihitung dengan persamaan:

$\%$ susut masak $=$

$\frac{\text { Berat sebelum dimasak-berat setelah dimasak }}{\text { Berat sebelum dimasak }} \times 100$

\section{Analisis Data}

Seluruh data hasil uji dianalisis secara desktriptif. Korelasi antara nilai $\mathrm{pH}$ dengan parameter lain dianalisis menggunakan koefisien korelasi Pearson. Seluruh data diolah menggunakan software Microsof Excell.

\section{HASIL DAN PEMBAHASAN}

\section{Komposisi Kimia Daging Pipi}

Kadarair daging pipiberkisar pada 75,75 $\pm 0,25 \%$, tidak berbeda dari yang dilaporkan Rotta et al. (2009) pada otot Longissimus dari sapi Nellore, yaitu 75,1 \pm 0,38\% (Tabel 1). Huff-Lonergan (2010) mengemukakan bahwa di dalam otot, air adalah komponen utama cairan ektrakseluler, sedangkan di dalam sel sebagai cairan sitoplasma yang berperan dalam proses termoregulasi, media dalam proses seluler sel, dan untuk transportasi nutrisi. Air yang dikandung dan tertahan di dalam otot adalah air yang terdapat di dalam myofibril, antara myofibril dan selaput sel (sarcolemma), antara sel otot dan antara kumpulan otot (Offer and Cousins, 1992). Air di dalam otot terbagi atas tiga bagian sebagaimana Abustam (2012), yaitu air terikat secara kimiawi oleh protein otot, air ini tidak mudah mengalami pergerakan; air yang terikat agak lemah (air yang terperangkap), yaitu air yang tertahan dalam struktur otot tetapi tidak terikat oleh protein, dan air ini akan terikat oleh protein jika tekanan uap air meningkat; dan air bebas, yaitu air yang mengalir dari jaringan tanpa hambatan. Huff-Lonergan and Lonergan (2005) menyatakan bahwa air yang 
JPI Vol. 22 (1): 89-100

Tabel 1. Komposisi kimia daging pipi (\%)

\begin{tabular}{lcc}
\hline & Nilai kisaran & Nilai rataan \pm sd \\
\hline Air & $75,55-76,03$ & $75,75 \pm 0,25$ \\
Protein & $21,87-22,33$ & $22,25 \pm 0,35$ \\
Lemak & $0,20-0,32$ & $0,31 \pm 0,02$ \\
Karbohirat & $0,85-1,25$ & $0,99 \pm 0,23$ \\
Abu & $0,95-1,05$ & $0,99 \pm 0,05$ \\
\hline
\end{tabular}

Keterangan: Rataan $\pm \mathrm{sd}(\mathrm{n}=3), \mathrm{sd}=$ standard deviasi, $\mathrm{n}=$ jumlah sampel

berperan dalam proses konversi otot menjadi daging adalah jenis air yang terperangkap.

Protein daging pipi sekitar 22,25 \pm $0,35 \%$, dan merupakan komponen terbesar kedua otot setelah air. Protein pada otot dapat bervariasi antara 16-22\% (Huff-Lonergan, 2010), sebagaimana juga yang dilaporkan oleh Hoffman et al. (2012) pada beberapa jenis otot bangsa sapi South African, bahkan dapat mencapai 24,0\% (Rotta et al., 2009). Protein adalah representasi kadar asam amino yang merupakan sumber nutrisi penting pangan konsumsi manusia. Pada otot sendiri, protein terdiri atas protein terlarut (protein sarkoplasma), yaitu protein yang terlibat dalam proses pensinyalan seluler dan enzim yang penting dalam metabolisme dan degradasi protein; dan protein tidak mudah larut (kecuali pada kekuatan ion yang lebih tinggi), adalah protein yang terlibat langsung dalam proses pergerakan (protein kontraktil, protein miofibrilar) dan protein yang mengatur interaksi antara protein kontraktil (HuffLonergen, 2010). Lebih lanjut disebutkan bahwa protein otot mempunyai fungsi yang beragam, dan fungsi utama protein diperankan oleh miofibrilar dengan komponen aktin dan miosinnya dan sejumlah organel lain yang terlibat dalam proses kontraksi-relaksasi otot.

Kadar lemak pada daging pipi cukup rendah yaitu sekitar $0,31 \pm 0,02 \%$ dibandingkan dengan kadar lemak yang dilaporkan pada jenis otot skeletal yang lain, yaitu lebih dari 1\% (Hoffman et al., 2012; Rotta et al., 2009). Rendahnya kadar lemak ini mungkin ada kaitannya dengan intensitas aktivitas otot pipi, dimana aktivitas mengunyah menyebabkan tidak tersisanya cadangan energy yang dapat dirombak menjadi deposit lemak akibat penggunaan energy yang berjalan efektif sepanjang waktu. Tetapi kadar lemak bisa bervariasi tergantung pada usia hewan, tingkat gizi hewan, dan jenis otot (Huff-Lonergan, 2010).

Kadar karbohidrat pada daging pipi adalah sekitar 0,99\%. Cobos and Diaz (2014) menyebutkan bahwa kadar karbohidrat otot berkisar antara 0,5-1,5\%, yang terutama merupakan cadangan glikogen dengan fungsi sebagai sumber energi bagi otot, ketika konversi otot menjadi daging. Kadar glikogen otot adalah salah satu indikator yang menentukan kualitas daging. Glikogen merupakan substrat utama dalam proses metabolik yang akan menghasilkan asam laktat pada konversi otot menjadi daging, menyebabkan terjadinya penurunan pada nilai $\mathrm{pH}$ dan berimplikasi terhadap karaktristik daging yang lain, diantaranya daya mengikat air dan warna daging (Aberle et al., 2001; Abustam, 2012). Kadar abu yang dikandung daging pipi adalah $0,99 \%$ dan tidak berbeda nyata dengan kadar abu otot longissimus sapi Simmental muda (Ćirić et al., 2017). Hasil penelitian menunjukkan bahwa komposisi kimia daging pipi pada dasarnya menyerupai daging skeletal pada umumnya (Huff-Lonergan, 2010; Onyango et al., 1998; Williams, 2007).

\section{Karakteristik Daging Pipi Sapi Bali}

Hasil pengamatan nilai $\mathrm{pH}$ daging pipi sapi sekitar 6 jam postmortem berkisar pada 5,73 sampai 6,01 $(5,91 \pm 0,07)$ (Tabel 2), lebih rendah dari nilai $\mathrm{pH} 24$ jam yang dilaporkan oleh Talmant et al. (1986) pada daging pipi 
Tabel 2. Karakteristik daging pipi

\begin{tabular}{lcc}
\hline & Nilai kisaran & Nilai rataan \pm sd \\
\hline $\mathrm{pH}$ & $5,73-6,01$ & $5,86 \pm 0,11$ \\
$\mathrm{mg} \mathrm{H} \mathrm{H}_{2} \mathrm{O}$ & $32,64-51,64$ & $42,24 \pm 7,60$ \\
Susut masak (\%) & $26,84-35,90$ & $31,57 \pm 3,36$ \\
Daya putus daging $\left(\mathrm{kg} / \mathrm{cm}^{2}\right)$ & $2,96-3,53$ & $3,12 \pm 0,33$ \\
Warna & & \\
$\quad L$ & $33,86-43,13$ & $39,12 \pm 3,44$ \\
$\quad a^{*}$ & $18,29-24,78$ & $22,97 \pm 2,77$ \\
$\quad b^{*}$ & $0,80-3,85$ & $2,57 \pm 1,27$ \\
\hline
\end{tabular}

Keterangan: Rataan $\pm \mathrm{sd}(\mathrm{n}=5), \mathrm{Sd}=$ standard deviasi, $\mathrm{n}=$ jumlah sampel, $\mathrm{mg} \mathrm{H}_{2} \mathrm{O}=$ miligram air, $\mathrm{L}=$ kecerahan, $a^{*}=$ kemerahan, $b^{*}=$ kekuningan

sapi yaitu sekitar 6,20 dan Vasudevan and Venkataramanujam (2012) pada daging pipi kerbau $(6,46 \pm 0,02)$. Nilai $\mathrm{pH}$ daging pipi hasil penelitian relatif sedikit agak tinggi $(0,21$ poin $)$ dibanding $\mathrm{pH}$-ultimat normal daging sapi (5,3-5,7) (Aberle et al., 2001).

Nilai $\mathrm{pH}$ daging pipi pada 6 jam postmortem masih relatif tinggi dari nilai $\mathrm{pH}$ normal. Keadaan ini ada kaitannya dengan kondisi ternak antemortem. Cadangan glikogen berkurang akibat aktivitas otot maupun faktor lain yang berpotensi menyebabkan stress (kekurangan pakan, cekaman panas, transportasi dan sebagainya) yang terus berlangsung sesaat sebelum ternak disembelih. Tidak ada catatan maupun informasi latar belakang sapi Bali yang disembelih baik jenis kelamin, pakan maupun aktivitas lain sebelum penyembelihan, kecuali umur (4-5 tahun), sehingga diasumsikan bahwa sapi yang disembelih berada pada kondisi yang relatif sama. Henckel et al. (2000) berpendapat bahwa penurunan nilai $\mathrm{pH}$ setelah hewan mati dipengaruhi oleh kondisi fisiologis otot dan ini berhubungan dengan produksi asam laktat maupun kapasitas produksi energi otot dalam bentuk ATP. Terjadinya penurunan $\mathrm{pH}$ ini disinyalir akibat berkurangnya oksigen dalam darah dalam waktu yang singkat setelah postmortem sehingga proses oksidasi terhenti dan beralih pada proses glikolisis yang menghasilkan asam laktat. Menurut Puolanne et al. (2002) asam laktat yang dihasilkan pada dasarnya ditujukan untuk mempertahankan kadar ATP dalam tingkat yang normal (homeostasis).

\section{Hubungan Antara Beberapa Karakteristik Daging Pipi Sapi Bali}

Hasil analisis menunjukkan ratarata daya mengikat air daging pipi yang direfleksikan sebagai $\mathrm{mg}_{2} \mathrm{O}$ yang terlepas dari otot adalah antara 32,64 sampai 51,64 $\mathrm{mg}$ air (42,24 $\pm 7,60 \mathrm{mg}$ air) (Tabel 2). Hasil analisis koefisien korelasi (r) menunjukkan ada hubungan yang sangat kuat antara $\mathrm{pH}$ dan daya mengikat air, yaitu $r=-0,92$ (Tabel 3). Ini mengindikasikan bahwa semakin rendah $\mathrm{pH}$ maka kemampuan otot dalam melepaskan air semakin tinggi. Berdasarakan persamaan garis menunjukkan bahwa setiap penurunan $\mathrm{pH} 0,1$ poin akan menyebabkan daging pipi melepaskan air sebesar $6,58 \mathrm{mg}$ dengan $\mathrm{R}^{2}=0,85$ (Gambar 1). Tidak ada standard yang menunjukkan nilai besaran daya mengikat air daging, tetapi secara umum telah diilustrasikan oleh Abustam (2012) dan Pereira et al. (2016) menyebutkan bahwa kemampuan mengikat air daging pipi berada pada kisaran sedang (intermediate binding capacity) sebagaimana yang dikuatkan oleh penelitian Komariah et al. (2009) terhadap daya mengikat air otot longissimus dorsi sapi yang lebih tinggi dibanding yang diperoleh pada hasil penelitian.

Kemampuan daging untuk mengikat air merupakan sifat kompleks yang dipengaruhi 


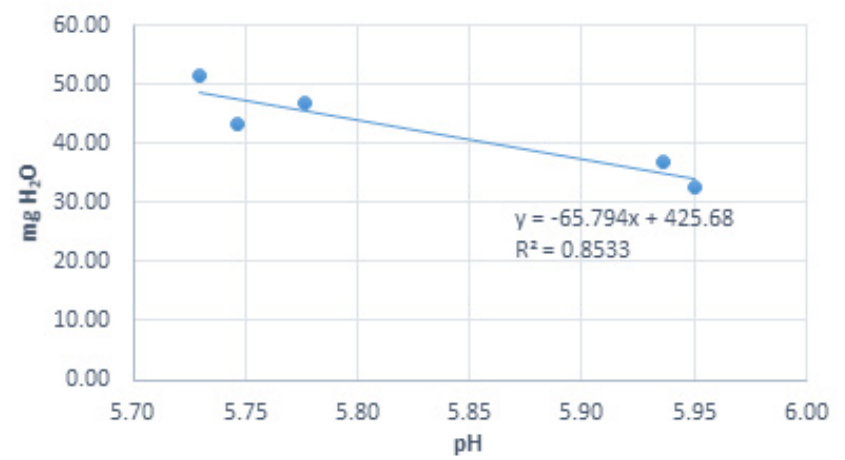

Gambar 1. Hubungan laju penurunan nilai $\mathrm{pH}$ terhadap daya mengikat air daging pipi sapi Bali $\left(\mathrm{mg} \mathrm{H}_{2} \mathrm{O}\right)$

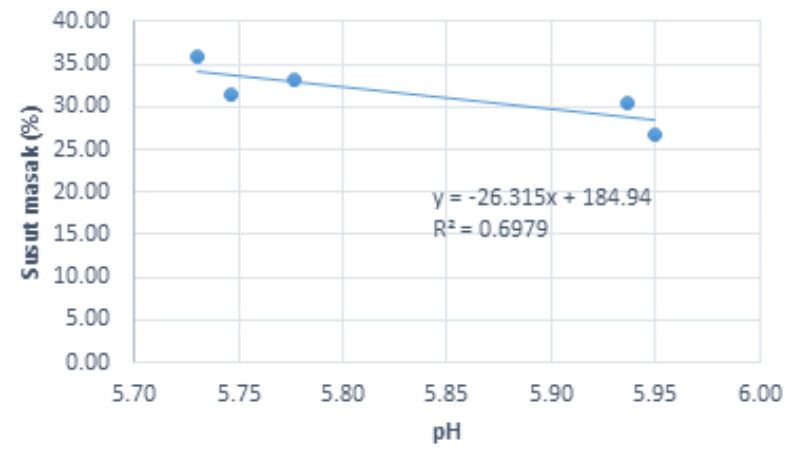

Gambar 2. Hubungan laju penurunan $\mathrm{pH}$ dan susut masak daging pipi sapi Bali

oleh perubahan struktural dan biokimiawi yang terjadi selama transformasi otot menjadi daging (Bowker and Zhuang, 2018), tetapi variasinya dapat bergantung pada sejumlah faktor antara lain $\mathrm{pH}$, status ternak (umur, kelamin, spesies), letak otot, pakan, transportasi, suhu, dan perlakuan sebelum dan setelah penyembelihan (Abustam, 2012). Penurunan kadar air daging pipi sebagaimana pada daging secara umum menurut Joo et al. (1995) dan Listrat et al. (2016) disebabkan oleh tingkat penurunan $\mathrm{pH}$, dimana perlakuan sebelum dan setelah penyembelihan maupun faktor intrinsik ternak tercermin pada tingkat penurunan $\mathrm{pH}$. Penurunan $\mathrm{pH}$ ini menyebabkan asam laktat terakumulasi dalam otot, tetapi keadaan ini tergantung pada kondisi ternak antemortem. Aksi asam laktat dalam otot mengakibatkan terjadinya denaturasi protein otot, sebagaimana Schafer et al. (2002) menjelaskan bahwa penurunan $\mathrm{pH}$ postmortem berakibat pada perubahan terhadap tingkat molecular, seperti penyusutan pada kisi miofilamen dan jembatan silang aktomiosin, penyusutan pada miofibrilar dan kontraksi serta denaturasi myosin; sealin itu, terjadi perubahan struktural pada serat dan serabut bundel sehingga memperluas ruang esktra selular; dan terjadi perubahan permeabilitas terhadap air dalam sel dan membrane basal.

Susut masak daging pipi pada 6 jam postmortem menunjukkan nilai kisaran 26,84$35,90 \%$ atau sekitar $31,57 \pm 3,36 \%$ (Tabel 2). Atribut penting lain dari kualitas daging adalah susut masak. Terdapat korelasi yang sangat kuat antara $\mathrm{pH}$ dan susut masak, yaitu $\mathrm{r}=-0,84$, dengan kata lain jika $\mathrm{pH}$ daging semakin rendah maka sebaliknya pada susut masak. Kondisi ini tergambar pada tingkat linearitas persamaan garis hubungan laju antara $\mathrm{pH}$ dan susut masak (Gambar 2). Dari persamaan tersebut menunjukkan bahwa terjadi kenaikan persentase susut masak 
Tabel 3. Hubungan antara beberapa karakteristik daging pipi $\left(\mathrm{pH}, \mathrm{mg}_{2} \mathrm{O}\right.$, susut masak, daya putus daging, nilai $L, a^{*}$ dan $b^{*}$ ) berdasarkan analisis uji korelasi Pearson $(r)$

\begin{tabular}{lccccccc}
\hline Item & $\mathrm{pH}$ & $\mathrm{mg} \mathrm{H}_{2} \mathrm{O}$ & $\begin{array}{c}\text { Susut } \\
\text { masak }\end{array}$ & $\begin{array}{c}\text { Daya putus } \\
\text { daging }\end{array}$ & $L$ & $a^{*}$ & $b^{*}$ \\
\hline $\mathrm{pH}$ & 1 & & & & & & \\
$\mathrm{mg} \mathrm{H} \mathrm{H}_{2} \mathrm{O}$ & $-0,925^{*}$ & 1 & & & & & \\
Susut masak & $-0,836$ & $0,974^{* *}$ & 1 & & & & \\
Daya putus daging & 0,659 & $-0,374$ & $-0,222$ & 1 & & & \\
$L$ & $-0,623$ & 0,659 & 0,525 & $-0,257$ & 1 & & \\
$a^{*}$ & $-0,710$ & 0,510 & 0,302 & $-0,723$ & 0,798 & 1 & \\
$b^{*}$ & $-0,564$ & 0,415 & 0,215 & $-0,434$ & 0,849 & $0,929^{*}$ & 1 \\
\hline
\end{tabular}

Keterangan: $*(\mathrm{P}<0,05), * *(\mathrm{P}<0,01)$

sebesar $2,63 \%$ setiap terjadinya penurunan pH 0,1 poin.

Terjadinya peningkatan pada persentase susut masak ada hubungannya dengan daya mengikat air daging. Hal ini dapat dijelaskan berdasarkan Gambar 3, dimana terdapat korelasi positif antara kenaikan persentase susut masak dengan air yang dilepaskan oleh otot, dengan $r=0,97$. Nilai $r$ yang tinggi ini mengindikasikan keterkaitan yang erat antara susut masak dengan daya mengikat air. Berdasarkan persamaan linear memperlihatkan bahwa setiap terjadi kenaikan persentase susut masak sebesar $0,43 \%$ menyebabkan terjadinya pelepasan air otot sebesar $10 \mathrm{mg}$ dengan $\mathrm{R}^{2}=0,95$. Hubungan positif antara susut masak dengan kemampuan otot melepaskan airnya (mg $\mathrm{H}_{2} \mathrm{O}$ ), menurut Ekiz et al. (2009) diakibatkan oleh terjadinya penurunan $\mathrm{pH}$.

Daging pipi sapi pada penelitian ini termasuk tipe daging yang memiliki susut masak relatif sedang yaitu sekitar $31,57 \pm$ 3,36\% jika dibandingkan hasil penelitian Komariah et al. (2009) pada otot Longissimus ternak sapi pada jam pengamatan yang sama, yaitu $41,40 \pm 0,39 \%$, tetapi lebih rendah dari daging domba $(28,54 \pm 0,92 \%)$ dan tidak berbeda jauh dengan daging kerbau $(31,40$ $\pm 0,38 \%$ ). Menurut Lawrie et al. (2003) kisaran susut masak dapat bervairiasi dari $1,5 \%$ sampai $54,5 \%$. Perbedaan pada susut masak ini, akan tetapi dapat dipengaruhi oleh perbedaan letak otot dan jenis ternak.
Termasuk atribut parameter kualitas daging yang berkaitan dengan kandungan air dalam daging adalah susut masak. Kadar air terlepas setelah pemanasan yang sedikit berimplikasi pada susut masak yang rendah. Hal ini menurut Aaslyng et al. (2003) mengindikasikan kemampuan daging mengikat air relatif tinggi. Sebagaimana Shanks et al. (2002) juga menyebutkan bahwa besarnya susut masak tidak terlepas dari faktor seperti kerusakan pada membran seluler, daya ikat air rendah serta degradasi protein.

Kualitas daging yang lain adalah keempukan. Keempukan dapat diduga dengan mengukur daya putus daging. Kisaran daya putus daging pipi adalah 2,96 sampai $3,53 \mathrm{~kg} /$ $\mathrm{cm}^{2}$ atau rata-rata $3,12 \pm 0,33 \mathrm{~kg} / \mathrm{cm}^{2}$ (Tabel 2). Daya putus daging pipi menunjukkan nilai yang lebih tinggi dibanding hasil penelitian Adha (2015) pada tiga jenis otot yang berbeda yaitu Longissimus, Semitendinosus dan Infraspinatus yaitu berturut-turut 2,49, 3,04, dan $2,64 \mathrm{~kg} / \mathrm{cm}^{2}$.

Uji korelasi Pearson menunjukkan ada hubungan yang kuat antara $\mathrm{pH}$ dan daya putus daging yaitu $r=0,66$, ini sebagaimana pernyataan Coleman et al. (2016) bahwa ada korelasi $\mathrm{pH}$ ultimat dengan daya putus daging. Analisis regresi menunjukkan terjadi penuruan daya putus daging sebesar $0,20 \%$ jika terjadi penurunan nilai $\mathrm{pH} 0,1$ poin, dengan $\mathrm{R}^{2}=0,43$ (Gambar 4). Rendahnya nilai $\mathrm{R}^{2}$ menunjukkan bahwa ada faktor lain selain $\mathrm{pH}$ yang mempengaruhi daya putus 


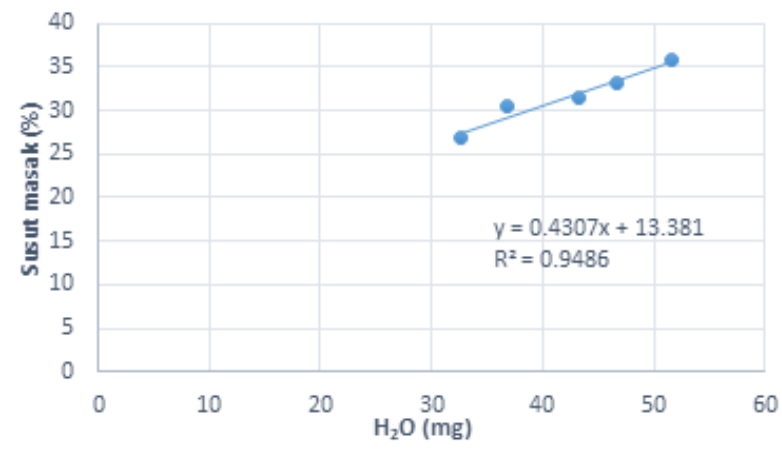

Gambar 3. Hubungan antara daya mengikat air dan susut masak daging pipi sapi Bali

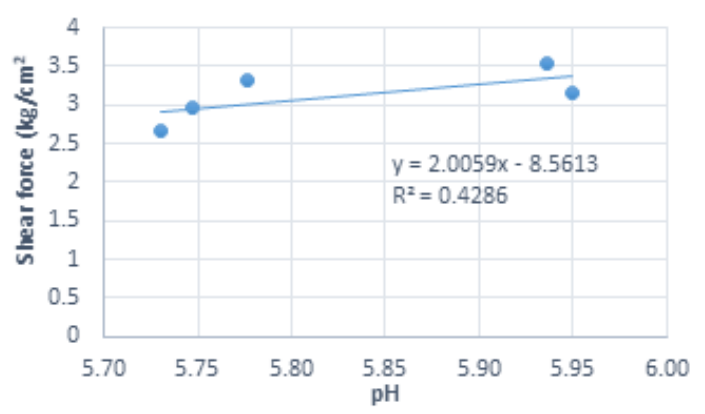

Gambar 4. Hubungan laju penurunan $\mathrm{pH}$ dan daya putus daging pipi sapi Bali $\left(\mathrm{kg} / \mathrm{cm}^{2}\right)$

daging, termasuk daya mengikat air, jaringan ikat dan lemak intramuscular (Ablikim et al., 2015; Wyrwisz et al., 2012). Terdapat korelasi negatif yang sangat kuat antara daya putus daging dengan daya mengikat air yaitu $r=-0,61$ dan berdasarkan persamaan garis (Gambar 5) menunjukkan bahwa jika terjadi penurunan pada air otot sebesar $14,15 \mathrm{mg}$ maka akan berakibat pada meningkatnya daya putus daging sebesar $1 \mathrm{~kg} / \mathrm{cm}^{2}$ dengan $\mathrm{R}^{2}=$ 0,14 .

Daya putus daging yang tinggi mengindikasikan bahwa daging cenderung alot. Daya putus daging pipi terindikasi lebih tinggi dibanding beberapa jenis otot pada bagian lainnya. Hal ini dapat dihubungkan dengan sifat daging pipi yang relatif hampir tidak mengandung lemak, tetapi banyak mengandung jaringan ikat.

Warna daging adalah salah satu atribut penting tingkat ketertarikan konsumen dalam menilai daging. Warna daging pipi yang diukur menggunakan colorimeter memiliki tingkat kecerahan, kemerahan dan kekuningan yang disimbolkan dengan $L, a^{*}$ dan $b^{*}$. Nilai notasi warna diantara sampel daging pipi yang diamati menunjukkan nilai yang cukup bervariasi, dan ini ada kaitannya dengan penurunan $\mathrm{pH}$. Nilai $L$ daging pipi berkisar pada 33,86 sampai 43,13 dengan rataan pada 39,12 $\pm 3,44$ dengan kofisien korelasi terhadap $\mathrm{pH}$ adalah $\mathrm{r}=-0,62$. nilai $a^{*}$ berkisar pada 18,29 sampai 24,78 atau sekitar $22,97 \pm 2,77$ dan $\mathrm{r}=-0,71$, dan nilai $b$ * berada pada kisaran 0,80 sampai 3,85 atau sekitar $2,57 \pm 1,27$ dan $r=-0,56$ (Tabel 2). Warna daging pipi menunjukkan korelasi yang kuat dengan $\mathrm{pH}$. Berdasarkan persamaan garis (Gambar 6) menunjukkan penurunan pada tingkat kecerahan $(L)$, kemerahan $\left(a^{*}\right)$ dan kekuningan $\left(b^{*}\right)$ daging pipi secara berturtturut yaitu sekitar $2,1\left(\mathrm{R}^{2}=0,38\right), 1,8\left(\mathrm{R}^{2}=\right.$ $0,50)$ dan $0,59\left(\mathrm{R}^{2}=0,32\right)$ seiring terjadinya peningkatan terhadap nilai $\mathrm{pH}$ sebesar 0,1 poin.

Tingkat kecerahan $(L)$ daging pipi relatif berada pada kisaran sebagaimana yang dilaporkan oleh Coleman et al. (2016) Page 


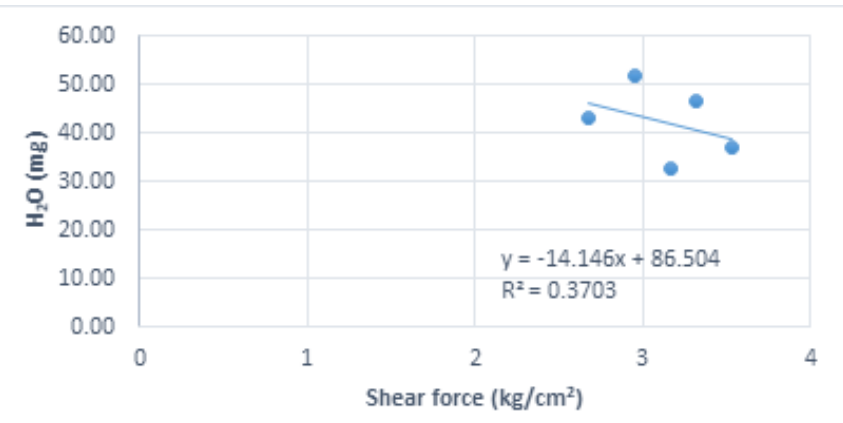

Gambar 5. Hubungan laju pelepasan air pada otot (mg) terhadap daya putus daging pipi sapi Bali $\left(\mathrm{kg} / \mathrm{cm}^{2}\right)$

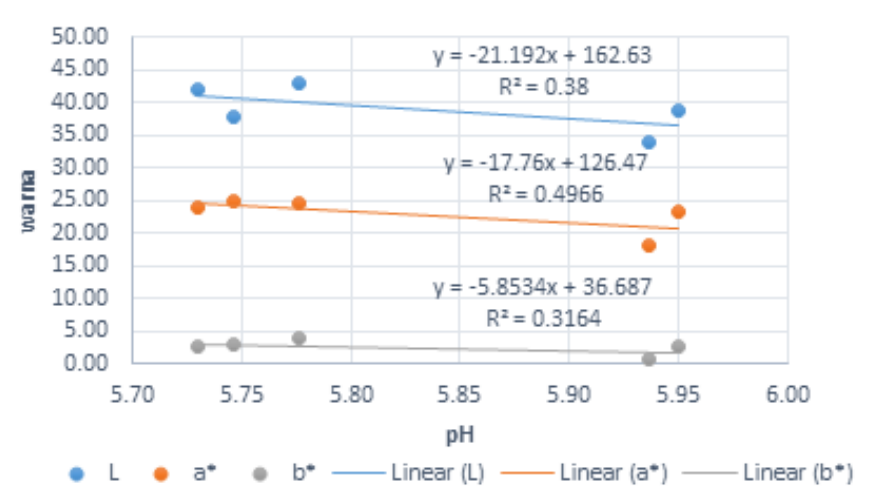

Gambar 6. Hubungan laju perubahan $\mathrm{pH}$ terhadap warna daging pipi sapi Bali

et al. (2001); Samootkwam et al. (2015) yaitu pada kisaran 37 sampai 41, meskipun nilai $\mathrm{pH}$ otot yang mereka laporkan sedikit lebih rendah dari hasil penelitian, tetapi tingkat korelasinya sangat kuat. Nilai $a^{*}$ hasil penelitian berada pada kisaran yang relatif sedikit lebih rendah dari yang dilaporkan Page et al. (2001) pada otot longissimus beberapa jenis sapi yaitu berkisar pada 23,40 (sapi perah), 24,78 (heifer), 25,20 (steer) dan 25,17 (Brahman); dan lebih tinggi dari yang dilaporkan oleh Coleman et al. (2016) pada otot longissimus beberapa bangsa sapi persilangan. Otot sapi yang dilaporakan tersebut memiliki nilai $\mathrm{pH}$ yang berada pada kisaran $\mathrm{pH}$ normal $(5,4$ sampai 5,7), dibanding hasil penelitian. Keragaman pada nilai $a^{*}$ dapat dihubungkan dengan kadar myoglobin otot (Page et al., 2001). Warna daging yang mengarah pada kekuningan dinotasikan sebagai $b^{*}$ menunjukkan nilai yang cukup rendah dibanding nilai $b^{*}$ beberapa jenis otot yang dilaporkan oleh (Diniz et al., 2016; Page et al, 2001; Stadnik and Dolatowsky, 2011; Wyrwisz et al., 2012). Intensitas $\mathrm{b}^{*}$ oleh Colemen et al. (2016) lebih dikaitkan dengan tingkat perlekatan lemak pada daging; atau mungkin jaringan ikat yang banyak terdapat pada daging pipi (Wyrwisz et al., 2012).

Terdapat korelasi negatif antara nilai $\mathrm{pH}$ dengan warna otot daging pipi. Pasca penyembelihan, $\mathrm{pH}$ cenderung menurun akibat proses glikolisis, hal ini menyebabkan warna daging menjadi lebih cerah. Sebaliknya pada $\mathrm{pH}$ di atas $\mathrm{pH}$ normal, warna cenderung mengarah pada warna merah gelap. Menurut (Wyrwisz et al., 2012) ketika $\mathrm{pH}$ berada di atas $\mathrm{pH}$ normal, protein menyerap air di otot sehingga serat otot lebih kencang, menyebabkan dispersi cahaya ke permukaan menjadi berkurang, tetapi otot dengan $\mathrm{pH}$ lebih rendah maka tingkat air bebasnya 
semakin banyak sehingga akan banyak serabut otot yang membengkak, menyebabkan warna myoglobin akan terpantul dan secara visual menghasilkan perpaduan intensitas warna yang lebih terang. Warna merah cerah pada daging merupakan refleksi dari kandungan myoglobin dalam daging (Suman and Joseph, 2013). Ini menunjukkan bahwa perbedaan jenis ternak, letak otot dan aktivitas otot dapat menghasilkan perbedaan pada warna daging (Abustam, 2012).

\section{KESIMPULAN}

Hasil penelitian menunjukkan baik komposisi kimia maupun karakteristik fisiko-kimia daging pipi tidak berbeda jauh dengan otot skeletal pada umumnya. Dengan demikian meskipun otot pipi bukan bagian dari otot skeletal, akan tetapi sifat-sifat otot pada umumnya melekat pada otot ini sehingga direkomendasikan untuk dijadikan sebagai daging alternatif dalam pengolahan berbagai jenis pangan hewani antara lain bakso dan sosis.

\section{DAFTAR PUSTAKA}

Aaslyng, M. D., C. Bejerholm, P. Ertbjerg, H. C. Bertram, and H. J. Andersen. 2003. Cooking loss and juiciness of pork in relation to raw meat quality and cooking procedures. Food Quality and Preference, 14: 277-288.

Aberle, E. D., J. C. Forrest., D. E. Gerrard, and E. W. Mills. 2001. Principles of Meat Science. Iowa: Kendall/Hunt Publishing Company. 354 p.

Ablikim, B., Y. Liu, A. Kerim, P. Shen, P. Abdurerim, and G. H. Zhou. 2016. Effects of breed, muscle type, and frozen storage on physico-chemical characteristics of lamb meat and its relationship with tenderness. CyTA Journal of Food, 14(1): 109-116.

Abustam, E. 2012. Meat Science: Aspects of Production, Chemistry, Biochemistry and Quality. $1^{\text {st }}$ Ed. Masagena Press. Makassar.

Adha, N. 2015. Karakteristik Fisik Daging Sapi Bali Hasil Penggemukan Menggunakan Pakan dengan Level Kulit Biji Kakao dan Otot Berbeda. Skripsi. Fakultas Peternakan Universitas Hasanuddin.

Assosiation of Official Analytical Chemists (AOAC). 1995. Official Methods of Analysis (16 $6^{\text {th }}$ ed.). Washington, DC.

Bowker, B. and H. Zhuang. 2015. Relationship between water-holding capacity and protein denaturation in broiler breast meat. Poultry Science, 94:1657-1664.

Ćirić, J., M. Lukić, S. Radulović, J. Janjić, N. Glamočlija, R. Marković, and M. Ž. Baltić. 2017. The relationship between the carcass characteristics and meat composition of young Simmental beef cattle. IOP Conf. Ser.: Earth Environ. Sci. 85012061.

Cobos, Á. and O. Díaz. 2014. Chemical Composition of Meat and Meat Products. In: Cheung P. (eds) Handbook of Food Chemistry. Springer, Berlin, Heidelberg.

Coleman, L. W., R. E. Hickson, N. M. Schreurs, N. P. Martin, P. R. Kenyon, N. Lopez-Villalobos, and S. T. Morris. 2016. Carcass characteristics and meat quality of Hereford sired steers born to beef-cross-dairy and Angus breeding cows. Meat Science, 121: 403-408.

Ekiz, B., A. Yilmaz, M. Ozcan, C. Kaptan, H. Hanoglu, I. Erdogan, and H. Yalcintan. 2009. Carcass measurements and meat quality of Turkish Merino, Ramlic, Kivircik, Chios and Imroz lambs raised under an intensive production system. Meat Science, 82: 64-70.

Henckel, P., A. Karlsson, N. Oksbjerg, and J. S. Petersen. 2000. Control of Postmortem $\mathrm{pH}$ decrease in Pig muscle: Experimental desigen and Testing of Animal Models. Meat Science, 55: 131-138. 
Hoffman, L. C., A. Vermaak, and N. Muller. 2012. Physical and chemical properties of selected beef muscles infused with a phosphate and lactate blend. South African Journal of Animal Sciences, 42(4): 317-340.

Huff-Lonergan, E. 2010. Chemistry and Biochemistry of Meat. In: Handbook of Meat Processing. Fidel Toldrá (ed). Wiley-Blackwell. Pp. 5-24.

Jayathilakan, K., K. Sultana, K. Radhakrishna, and A. S. Bawa. 2012. Utilization of byproducts and waste materials from meat, poultry and fish processing industries: A review. Journal of Food Science and Technology, 49(3): 278293.

Joo, S-T., R. G. Kauffman, B-C. Kim, and C-J. Kim. 1995. The relationship between color and water-holding capacity in postrigor porcine longissimus muscle. Journal of Muscle Foods, 6(3): 211226.

Komariah., S. Rahayu, dan Sarjito. 2009. Physical characteristics of beef, buffalo and lamb meat on different postmortem periods. Buletin Peternakan. 33(3): 183-189.

Lawrie, R. A. 2003. Meat Science. The 6th ed. Terjemahan. A. Paraksi dan A. Yudha. Penerbit Universitas Indonesia, Jakarta.

Listrat, A., B. Lebret, I. Louveau, T. Astruc, M. Bonnet, L. Lefaucheur, and J. Bugeon. 2016. How Muscle Structure and Composition Influence Meat and Flesh Quality. Scientific World Journal, 2016:3182746.

Marti, D. L., R. J. Johnson, and K. H. Mathews. 2011. Where's the (Not) Meat? By products From Beef and Pork Production. A Report from the Economic Research Service. USDA. www.ers.usda.gov

Onyango, C. A., M. Izumimoto, and P. M. Kutima. 1998. Comparison of physical and chemical properties of selected games meat. Meat Science, 49(1): 117-
125.

Page, J. K., D. M. Wulf, and T. R. Schwotzer. 2001. A survey of beef muscle color and $\mathrm{pH}$. Journal of Animal Science, 79: 678-687.

Pereira, J., G. Zhou, and W. Zhang. 2016. Effects of Rice Flour on Emulsion Stability, Organoleptic Characteristics and Thermal Rheology of Emulsified Sausage. Journal of Food and Nutrition Research, 4(4): 216-222.

Puolanne, E., A. R. Pösö, M. H. Ruusunen, K.V. Sepponen, and M.S. Kylä-Puhju. 2002. Lactic acid in muscle and its effects on meat quality. Proceedings of the 55th Reciprocal Meat Conference, 57-62.

Purslow, P. P. 2005. Intramuscular connective tissue and its role in meat quality. Meat Science, 70(3): 435-447.

Ranken, M. D. 2000. Handbook of Meat Product Technology. Blackwell Science.

Rotta, P. P., I. N. do Prado, R. M. do Prado, J. L. Moletta, R. R. Silva, and D. Perotto. 2009. Carcass Characteristics and Chemical Composition of the Longissimus Muscle of Nellore, Caracu and Holstein-friesian Bulls Finished in a Feedlot. Asian-Australasian Journal of Animal Sciences, 22(4): 598-604.

Samootkwam, K., S. Jaturasitha, B. Tipnate, A. Waritthitham, M. Wicke, and M. Kreuzer. 2015. Effect of Improving Lamphun Cattle with Black Angus on Carcass and Meat Quality. Agriculture and Agricultural Science Procedia 5: $145-150$.

Schafer, A., K. Rosenvold, P. P. Purslow, H. J. Andersen, and P. Henckel. 2002. Physiological and structural events postmortem of importance for drip loss in pork. Meat Science, 61: 355-366.

Shanks, B. C., D. M. Wolf, and R. J. Maddock. 2002. Technical note: The effect of freezing on Warner Bratzler shear force 
values of beef longissimus steak across several postmortem aging periods. Journal of Animal Science, 80: 21222125.

Stadnik, J.and J.Z. Dolatowski.2011. Influence of sonication on Warner-Bratzler shear force, colour and myoglobin of beef (m. semimembranosus). Eur Food Res Technol, 233:553-559.

Suman, S. P. and P. Joseph. 2013. Myoglobin Chemistry and Meat Color. Annual Review of Food Science and Technology, 4(1): 79-99.

Talmant, A., G. Monin, M. Briand, M. Dadet, and Y. Briand. 1986. Activities of metabolic and contractile enzymes in 18 bovine muscles. Meat Science, 18(1), 23-40.

Williams, P. G. 2007. Nutritional composition of red meat. Nutrition \& Dietetics, 64 (Suppl. 4): S113-S119.

Wyrwisz, J., A. Półtorak, M. Zalewska, R. Zaremba, and A. Wierzbicka. 2012. Analysis of Relationship Between Basic Composition, pH, and Physical Properties of Selected Bovine Muscles. Bulletin of the Veterinary Institute in Pulawy, 56(3): 403-409.

Vasudevan, V. N. and V. Venkataramanujam. 2012. Quality Characteristics of Buffalo Cheek Meat. Journal of Veterinary Animal Science, 43: 85-86. 